\title{
INTERNALIZATION OF $\alpha$-BUNGAROTOXIN ON NEURONS INDUCED BY A NEUROTOXIN THAT BLOCKS NEURONAL ACETYLCHOLINE SENSITIVITY ${ }^{1}$
}

\author{
PETER M. RAVDIN, ${ }^{2}$ RALPH M. NITKIN, AND DARWIN K. BERG ${ }^{3}$ \\ Department of Biology, University of California, San Diego, La Jolla, California 92093
}

\begin{abstract}
A protein neurotoxin (Bgt 3.1) present as a minor component in the venom of Bungarus multicinctus has been shown previously to block acetylcholine (ACh) sensitivity on chick ciliary ganglion (CG) neurons in cell culture. $\alpha$-Bungarotoxin (Bgt 2.2) binds to the neurons but does not block ACh sensitivity; the function of the Bgt 2.2 binding site is unknown. The present studies demonstrate that Bgt 3.1 can induce the rapid internalization of Bgt 2.2 bound on the surface of CG and sympathetic neurons.

The rapid internalization of bound Bgt 2.2 caused by Bgt 3.1 can be seen with fluorescence microscopy using rhodamine-labeled Bgt 2.2 as the probe and by immunological techniques using anti-Bgt 2.2 antiserum to locate the bound ${ }^{125} \mathrm{I}-\mathrm{Bgt} 2.2$. The rapid internalization is blocked by low temperature or by high concentrations of Bgt 2.2 and is not induced by Bgt 2.2 itself or by small cholinergic ligands. Bound ${ }^{125} \mathrm{I}-\mathrm{Bgt} 2.2$ is released into the medium as degraded material after internalization is induced. Bgt 3.1 does not induce internalization of Bgt 2.2 bound to skeletal myotubes in culture nor does it induce the internalization of rhodamine-labeled nerve growth factor bound to sympathetic neurons, suggesting that its effect on neuronally bound Bgt 2.2 might be a specific one.

Competition binding studies suggest that Bgt 3.1 may trigger the internalization of bound Bgt 2.2 by direct interaction with a Bgt 2.2 binding site. The effect of Bgt 3.1 on neuronal ACh sensitivity, however, does not depend on internalization of Bgt 2.2 binding sites since full inhibition of ACh sensitivity is still achieved by Bgt 3.1 under conditions where internalization is blocked. Neurons may have more than one class of Bgt 3.1 binding sites, e.g., a class that inhibits ACh sensitivity and a class that triggers internalization of Bgt 2.2 on the neurons. The internalization of Bgt 2.2 binding sites induced by Bgt 3.1 provides an unusual opportunity to study cellular mechanisms by which neurons can regulate the number and distribution of their surface components.
\end{abstract}

Many of the recent advances in understanding the regulation of acetylcholine $(\mathrm{ACh})$ receptors in muscle and electric tissue have resulted from the availability of specific protein $\alpha$-neurotoxins, such as $\alpha$-bungarotoxin (Bgt 2.2), that can be labeled with radioactive isotopes and that bind tightly and specifically to the receptors

\footnotetext{
${ }^{1}$ This work was supported by grants from the National Institutes of Health (NS 12601), the Muscular Dystrophy Association, and the American Heart Association with funds contributed in part by the California Heart Association. We thank Dr. Jim Patrick of the Salk Institute for the generous gift of purified Dendroaspis viridis long toxin and Dr. Jack Kyte of the University of California, San Diego, for determining the amino acid composition of neurotoxin Bgt 3.1. Marie Ryder prepared the cell cultures and provided expert technical assistance throughout. P. M. R. is a fellow of the Muscular Dystrophy Association of America.

${ }^{2}$ Current address: University of Miami School of Medicine, Miami, FL 33125 .

${ }^{3}$ To whom correspondence should be addressed.
}

(Fambrough, 1979). Bgt 2.2 also binds to neurons that have $\mathrm{ACh}$ receptors, but the relationship between the Bgt 2.2 binding site on neurons and the neuronal ACh receptor remains unclear. It has been found that concentrations of Bgt 2.2 adequate to saturate the binding site on avian and mammalian autonomic neurons have no effect on neuronal ACh sensitivity (Brown and Fumagalli, 1977; Patrick and Stallcup, 1977a; Carbonetto et al., 1978; Kouvelas et al., 1978; Ravdin and Berg, 1979; Chiappinelli et al., 1981). Furthermore, immunological studies on the pheochromocytoma cell line $\mathrm{PC} 12$ suggested that the two sites may be distinct. Antibodies against eel ACh receptor did block ACh receptor function in PC12 cells and did cross-react with some component in cell homogenates, but the antibodies did not cross-react with the Bgt 2.2 binding component either in whole cells or in cell homogenates (Patrick and Stallcup, 1977b).

Recently, we have identified two protein neurotoxins (Bgt 3.1 and Bgt 3.3) present as minor components in the 
venom of Bungarus multicinctus that do inhibit $\mathrm{ACh}$ receptor function on neurons (Ravdin and Berg, 1979). The purified toxins have apparent molecular weights of $\sim 6500$ and 8000 , respectively, as determined by polyacrylamide gel electrophoresis in sodium dodecyl sulfate. Very low concentrations of either Bgt 3.1 or Bgt 3.3 reversibly inhibit the sensitivity of ciliary ganglion neurons to iontophoretically applied $\mathrm{ACh}$. Under these conditions, the toxins had no effect on the mean resting potential and input resistance of the neurons, and they did not prevent generation of action potentials. These observations raised the possibility that either Bgt 3.1 or Bgt 3.3 might prove useful as a ligand for studying the regulation of neuronal ACh receptors.

We now report that Bgt 3.1 has a second effect on neuronal membrane components: it causes the rapid internalization of $\mathrm{Bgt} 2.2$ bound on the surface of the cells. Blockade of neuronal ACh sensitivity by $\mathrm{Bgt} 3.1$, however, can be separated from the effect of Bgt 3.1 on Bgt 2.2 bound to the neurons.

\section{Materials and Methods}

Cell cultures. Ciliary ganglion (CG) neuron cultures were prepared with dissociated neurons from 8-day-old chick embryos as previously described (Nishi and Berg, 1977). For fluorescence microscopy studies, the neurons were usually grown with skeletal myotubes on glass bottom dishes (Ravdin and Berg, 1979). In some cases, CG neurons were grown alone on collagen-coated $35-\mathrm{mm}$ plastic dishes, and subsequently, the cultures were covered with a glass coverslip and inverted for fluorescence microscopy.

For binding studies with ${ }^{125} \mathrm{I}-\mathrm{Bgt} 2.2$, dissociated CG neurons were grown alone at a density of 2 to 4 ganglion equivalents (i.e., 1.3 to $2.6 \times 10^{5}$ neurons) per $16-\mathrm{mm}$ Falcon tissue culture well (Nishi and Berg, 1979). In these experiments, it was necessary to take special precautions to insure that the CG neurons remained firmly attached to the culture surface throughout the many incubation and wash steps. Accordingly, the wells first were seeded with chick fibroblasts prepared by trypsin dissociation of embryonic cephalic skin tissue. The fibroblasts were allowed to grow to confluency ( 2 to 3 days) and then were lysed by incubation with deionized water for $1 \mathrm{hr}$ at $37^{\circ} \mathrm{C}$. The wells were rinsed briefly, filled with culture medium, and seeded with CG neurons. The neurons attached firmly to the modified surface and remained uniformly distributed throughout the culture (Nishi and Berg, 1981).

Sympathetic neurons were grown either with skeletal myotubes in $35-\mathrm{mm}$ dishes or alone in $16-\mathrm{mm}$ wells exactly as described for $C G$ neurons except that the sympathetic neurons were obtained from 8-to 12-day-old chick embryos and were seeded at a density of one to two chains per culture (two chains of ganglia obtained per embryo). Myotube cultures were prepared as previously described (Nishi and Berg, 1977) except for cultures used in ${ }^{125} \mathrm{I}$-Bgt 2.2 binding experiments, in which case, the cells were seeded at $10^{5} / 16-\mathrm{mm}$ well. All cultures containing neurons were maintained in Eagle's minimal essential medium supplemented with $10 \%(\mathrm{v} / \mathrm{v})$ heatinactivated horse serum, $5 \%(\mathrm{v} / \mathrm{v})$ chick embryo extract,
$50 \mu \mathrm{g} / \mathrm{ml}$ of penicillin, and 50 units $/ \mathrm{ml}$ of streptomycin (Nishi and Berg, 1979); the medium was changed at 2- to 3-day intervals. Cultures containing sympathetic neurons were supplemented with $1 \mathrm{unit} / \mathrm{ml}$ of nerve growth factor (Burroughs-Wellcome).

Protein neurotoxins. $\alpha$-Bungarotoxin (Bgt 2.2) and neurotoxin Bgt 3.1 were purified from Bungarus multicinctus venom as previously described (Ravdin and Berg, 1979). In some cases, further purification of Bgt 3.1 was carried out to remove the remaining 5 to $10 \%$ impurities. To do this, Bgt 3.1 (16 mg) was loaded onto a carboxymethyl (CM) cellulose column (CM52, $15 \mathrm{ml}, 0.9 \times 23$ $\mathrm{cm})$ and was eluted with a linear salt gradient $(110 \mathrm{ml})$ containing 0.05 to $0.20 \mathrm{M} \mathrm{NaCl}$ in $0.05 \mathrm{M}$ ammonium acetate, $\mathrm{pH}$ 7.2. Radioimmune assays with ${ }^{125} \mathrm{I}$-Bgt 2.2 and anti-Bgt 2.2 antiserum indicated that Bgt 3.1 purified in this manner contained about $0.6 \%$ Bgt 2.2 (or an equivalent amount of cross-reacting material). For some of the competition binding studies between ${ }^{125} \mathrm{I}-\mathrm{Bgt} 2.2$ and Bgt 3.1 in neuronal cell culture, the Bgt 3.1 was purified further by passage over an affinity column constructed with anti-Bgt 2.2 antibodies. Radioimmune assays indicated that the recovered Bgt 3.1 contained, at most, $0.02 \%$ Bgt 2.2 (D. K. Berg, unpublished observations).

Tetramethyl rhodamine-conjugated Bgt 2.2 (R-2.2) was prepared and purified by the method of Ravdin and Axelrod (1977), and di $\left[{ }^{125} \mathrm{I}\right]$ iodo-Bgt 2.2 was prepared by the method of Vogel et al. (1972). Specific activities for the ${ }^{125}$ I-Bgt 2.2 preparations ranged from 150 to $400 \mathrm{cpm} /$ fmol. The concentration of Bgt 2.2 was calculated by using a value of $E_{0.1 \%}^{280}=1.3$ (Hanley et al., 1977; Patrick et al., 1980). The concentration of Bgt 3.1 was calculated by performing Lowry protein determinations (Lowry et al., 1951). To calibrate the Lowry assay, a solution of Bgt 3.1 also was examined for amino acid composition by Jack Kyte (University of California, San Diego). An apparent Bgt 3.1 concentration of $1 \mathrm{mg} / \mathrm{ml}$, as determined by the Lowry assay using bovine serum albumin as a standard, corresponds to an actual Bgt 3.1 concentration of $0.1 \mathrm{~mm}$ as indicated by amino acid analysis. This correction was applied routinely in determining Bgt 3.1 concentrations.

Nerve growth factor. The $7 \mathrm{~S}$ form of nerve growth factor (NGF) was purified as previously described (Burton et al., 1978), and the $\beta$ form ( $\beta$-NGF) was isolated from it by ion exchange chromatography on CM-cellulose (Varon et al., 1968). Tetramethyl rhodamine-conjugated $\beta$-NGF (R-NGF) was prepared by reacting $1.5 \mathrm{mg}$ of $\beta$ NGF with $19 \mu \mathrm{g}$ of tetramethyl rhodamine isothiocyanate in $1.1 \mathrm{ml}$ of $0.09 \mathrm{M} \mathrm{NaCO}_{3}, \mathrm{pH} 9.0$, for $1 \mathrm{hr}$ at room temperature. R-NGF was separated from unbound rhodamine by gel filtration through a Sephadex G-25 column equilibrated with $3.3 \mathrm{~mm} \mathrm{NaPO}$, pH 7.4.

Fluorescence microscopy. Cultures labeled with R-2.2 or R-NGF were prepared and examined with fluorescence microscopy as previously described (Ravdin and Berg, 1979). In nerve-muscle cultures, $R-2.2$ bound to neurons and myotubes, but the two types of binding usually could be distinguished clearly by comparing fluorescence and phase images and by adjusting the focal plane of the microscope. For incubations at $4^{\circ} \mathrm{C}$, the R-2.2-labeled 
cultures were rinsed three times with and incubated at $4^{\circ} \mathrm{C}$ in minimal essential medium (MEM) containing 5 mM HEPES (4-(2-hydroxyethyl)-1-piperazine-ethanesulfonic acid) buffer instead of bicarbonate buffer and supplemented with $1 \%(\mathrm{v} / \mathrm{v})$ horse serum, $0.2 \mathrm{gm} / \mathrm{liter}$ of sodium pyruvate, $5 \mathrm{mg} /$ liter of choline chloride, and $2 \%$ (v/v) 50x MEM nonessential amino acids. R-2.2 binding to intact ciliary ganglia was examined by placing labeled whole ganglia on a glass slide with a drop of culture medium, covering with a glass coverslip, and viewing directly with fluorescence microscopy.

Acetylcholine sensitivity. Acetylcholine (ACh) sensitivity for CG neurons grown in culture for 1 to 2 weeks was measured by using intracellular recording and iontophoretically applying $\mathrm{ACh}$ as previously described (Ravdin and Berg, 1979). A mean value for ACh sensitivity in millivolts per nanocoulomb $(\mathrm{nC})$ ) was calculated for a population of neurons for a given test condition, and the value was expressed as a percentage of that obtained for neurons in control cultures from the same series of plates assayed on the same day. In some cases, the same culture was used for the control and test condition by assaying neurons before and after exposure to the toxin. Results were pooled from several experiments. Control values, defined as $100 \%$, were usually about $100 \mathrm{mV} / \mathrm{nC}$, though considerable variation was observed for neurons within a culture and for cultures from different experiments (Ravdin and Berg, 1979).

${ }^{125} \mathrm{I}$-Bgt 2.2 binding. ${ }^{125} \mathrm{I}$-Bgt 2.2 binding was assayed at $37^{\circ} \mathrm{C}$ by incubating either 0.3 or $0.5 \mathrm{ml}$ of medium containing ${ }^{125} \mathrm{I}-\mathrm{Bgt} 2.2$ in $16-\mathrm{mm}$ culture wells. The cultures then were rinsed either four or five times with 1-ml aliquots of warm medium, scraped in $0.5 \mathrm{ml}$ of $0.6 \mathrm{~N}$ $\mathrm{NaOH}$, and counted for radioactivity with a Nuclear Chicago $\gamma$ counter. For binding studies at $4^{\circ} \mathrm{C}$, cultures were rinsed and incubated in chilled phosphate-buffered saline (PBSS) containing $1 \mathrm{mg} / \mathrm{ml}$ of bovine serum albumin and then rinsed with chilled culture medium.

For experiments in which the release of ${ }^{125}$ I-Bgt 2.2 from cells was examined, the cultures first were labeled at $37^{\circ} \mathrm{C}$ with ${ }^{12.5} \mathrm{I}$-Bgt 2.2 and rinsed as described above. The cultures then were incubated in $0.5 \mathrm{ml}$ of medium with or without $0.2 \mu \mathrm{M} \mathrm{Bgt} 3.1$ for $1 \mathrm{hr}$ at $37^{\circ} \mathrm{C}$, rinsed twice, given fresh medium, and returned to $37^{\circ} \mathrm{C}$. At various times afterward, cultures were rinsed once, scraped, and counted for radioactivity. The supernatant fraction from the final incubation and the rinse solution were pooled and counted to determine the amount of radioactivity released. Nonspecific binding was determined by labeling the cultures with ${ }^{125} \mathrm{I}-\mathrm{Bgt} 2.2$ in the presence of $1 \mu \mathrm{M}$ Bgt 2.2 and then processing the cultures as described above. Such values were always less than $5 \%$ of the experimental values and were subtracted where appropriate.

$P-2$ column gel filtration. Radioactive culture medium $(0.3 \mathrm{ml})$ was applied to â $\mathrm{P}-2$ column $(21 \times 0.8 \mathrm{~cm})$ equilibrated with PBSS containing $1 \mathrm{mg} / \mathrm{ml}$ of bovine serum albumin and $1 \mathrm{mM} 3,5$-di-iodo-L-tyrosine, and 0.50 $\mathrm{ml}$ fractions were collected. Recoveries of radioactivity from the columns were about $90 \%$.

Antibody/Staphylococcus assay. Anti-Bgt 2.2 antiserum was used to assay the fraction of neuronally bound
Bgt 2.2. that remained accessible to antibodies on intact cells. Cultures were labeled with ${ }^{125} \mathrm{I}$-Bgt 2.2 and washed as described above. Cultures were incubated further in fresh solution under the test conditions. The cultures then were rinsed once with cold PBSS ( $1 \mathrm{ml} /$ well) and incubated $0.5 \mathrm{hr}$ on ice in PBSS $(0.5 \mathrm{ml} /$ well $)$ containing anti-Bgt 2.2 antiserum and $1 \mathrm{mg} / \mathrm{ml}$ of ovalbumin. The cultures were rinsed again with cold PBSS ( $1 \mathrm{ml} /$ well $)$, homogenized in $\mathrm{T}$ buffer $(0.05 \mathrm{M}$ Tris, $\mathrm{pH} 7.4,0.15 \mathrm{M}$ $\mathrm{NaCl}, 0.1 \%$ Triton $\mathrm{X}-100,0.02 \%$ sodium azide, and $1 \mathrm{mg} /$ $\mathrm{ml}$ of ovalbumin; $0.5 \mathrm{ml} /$ well) containing $1 \mu \mathrm{M}$ Bgt 2.2 , and mixed with a $1.4 \%(\mathrm{w} / \mathrm{v})$ suspension $(0.5 \mathrm{ml})$ of fixed Staphylococcus aureus in $\mathrm{T}$ buffer to absorb the antigen. antibody complex (Kessler, 1975). The particulate fraction was collected by centrifugation at $12,800 \times g$ for 2 min, washed with $1 \mathrm{ml}$ of $\mathrm{T}$ buffer, and counted for radioactivity with a $\gamma$ counter. The supernatant fraction and wash solution were pooled and counted similarly.

Media and chemicals. Culture media and biological materials were obtained and prepared as described (Nishi and Berg, 1977). B. multicinctus venom was purchased from Miami Serpentarium, tetramethyl rhodamine isothiocyanate was from Research Organics, Inc., and cytochalasin B, colchicine, di-iodo-L-tyrosine, and concanavalin A were from Sigma. Fixed Staphylococcus aureus was purchased as a $10 \%(\mathrm{w} / \mathrm{v})$ suspension from Calbiochem. $\mathrm{Na}\left[{ }^{125} \mathrm{I}\right]$ was purchased from New England $\mathrm{Nu}$ clear and from Amersham/Searle. Dendroaspis viridis long toxin was the generous gift of Jim Patrick (Salk Institute) and has been shown to bind tightly and specifically to the Bgt 2.2 binding site on PC12 cells in culture (Patrick et al., 1980). Anti-Bgt 2.2 antiserum was raised in rabbits against purified Bgt 2.2. After centrifugation to remove clotted material and cells, the serum was stored frozen until use. The antiserum was specific for Bgt 2.2 and did not cross-react with Bgt 3.1 (Nitkin, 1981). PBSS was as previously described (Barald and Berg, 1978) except that glucose was omitted.

\section{Results}

Bgt 2.2 binding sites. Ciliary ganglion (CG) neurons grown in dissociated cell culture were found to have specific high affinity binding sites for Bgt 2.2. The sites could be saturated by incubation with $10 \mathrm{nM}{ }^{125} \mathrm{I}$-Bgt 2.2 for $1 \mathrm{hr}$ at $37^{\circ} \mathrm{C}$ (Fig. 1). Binding sites with similar properties have been described for Bgt 2.2 on CG neurons in whole ganglia (Chiappinelli and Giacobini, 1978; Fumagalli et al., 1978). When CG neurons were incubated with 40 nM rhodamine-labeled Bgt 2.2 (R-2.2) and examined with fluorescence microscopy, the fluorescent labeling was distributed in a patchy manner over the neuronal somata and processes (Fig. 2, $A$ and $B$ ). The fluorescent labeling was specific since incubation of the cells with $10 \mathrm{nM} \mathrm{Bgt} 2.2$ prior to R-2.2 treatment resulted in no detectable fluorescent labeling of the neurons.

Internalization induced by Bgt 3.1. Bgt 3.1 produced dramatic changes in the distribution of bound R-2.2 on the cells. When the neurons first were labeled with R-2.2 and then incubated with $0.2 \mu \mathrm{M} \mathrm{Bgt} 3.1$ for $1 \mathrm{hr}$ at $37^{\circ} \mathrm{C}$, very little $\mathrm{R}-2.2$ binding remained at the cell surface. Instead, numerous small intense foci of rhodamine fluorescence appeared scattered throughout the cell interior 


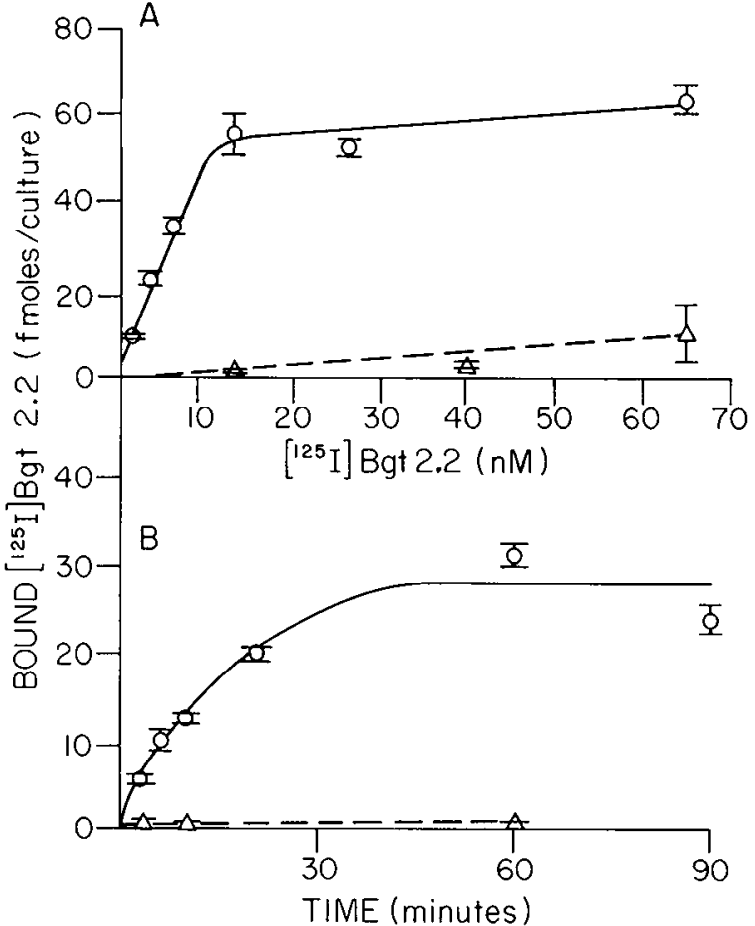

Figure 1. ${ }^{125} \mathrm{I}$-Bgt 2.2 binding to $\mathrm{CG}$ neurons in cell culture. One-week-old CG cultures were incubated at $37^{\circ} \mathrm{C}$ with ${ }^{125} \mathrm{I}-\mathrm{Bgt}$ 2.2 for total binding ( - ) and with ${ }^{125} \mathrm{I}-\mathrm{Bgt} 2.2$ together with $1 \mu \mathrm{M}$ unlabeled Bgt 2.2 for nonspecific binding (- - -). A, Binding as a function of ${ }^{125} \mathrm{I}$-Bgt 2.2 concentration for $1 \mathrm{hr}$. $B$, Binding as a function of time in $12 \mathrm{~nm}{ }^{125} \mathrm{I}$-Bgt 2.2. Each point represents the mean of three cultures; the bars indicate the SE. The 2-fold difference in the plateau levels of ${ }^{125} \mathrm{I}$-Bgt 2.2 binding in panels $A$ and $B$ reflect the variation found for cultures from different cell platings. Cultures from a single plating are in closer agreement as the points within a single panel indicate.

(Fig. 2, $C$ and $D$ ). By adjusting the focal plane of the microscope, it was possible to demonstrate that the punctate labeling induced by Bgt 3.1 was, in fact, distributed throughout the cell interior. The cell nucleus usually could be distinguished as a dark ovoid structure which excluded the fluorescent foci.

Internalization of bound R-2.2 was inhibited by low temperature. When R-2.2-labeled neurons were incubated with Bgt 3.1 at $4^{\circ} \mathrm{C}$, no internalization was observed (Fig. 2E). The fluorescence remained associated with the cell surface. When the cultures were washed to remove unbound Bgt 3.1 and then warmed to $37^{\circ} \mathrm{C}$, internalization proceeded as described (Fig. $2 F$ ). Clearly Bgt 3.1 was able to bind at $4^{\circ} \mathrm{C}$, but internalization of the bound R-2.2 was blocked at the low temperature. Induced internalization also was blocked when R-2.2-labeled neurons were treated with $0.1 \mathrm{mg} / \mathrm{ml}$ of concanavalin A for $1 \mathrm{hr}$ at $37^{\circ} \mathrm{C}$ prior to incubation with Bgt 3.1 (not shown). The induced internalization of R-2.2 was not blocked by $50 \mu \mathrm{M}$ colchicine or $200 \mu \mathrm{M}$ cytochalasin B. Little if any internalization occurred spontaneously over a period of several hours in the absence of Bgt 3.1 treatment, and high concentrations of Bgt $2.2(1 \mu \mathrm{M})$ did not induce internalization of the bound R-2.2, as judged by the absence of the characteristic punctate labeling. Incubation of CG neurons in $0.2 \mu \mathrm{M}$ Bgt 3.1 for $30 \mathrm{~min}$ at $37^{\circ} \mathrm{C}$ prior to labeling with R-2.2 prevented subsequent fluo- rescent labeling of the cells. Either Bgt 3.1 blocks Bgt 2.2 binding sites at $37^{\circ} \mathrm{C}$ or it induces internalization of the empty binding sites.

Internalization of bound R-2.2 also occurred with intact ciliary ganglia. Whole ganglia from 8-day-old embryos were incubated with $50 \mathrm{~nm}$ R-2.2 for $1 \mathrm{hr}$ at $37^{\circ} \mathrm{C}$ and then treated with $0.2 \mu \mathrm{M}$ Bgt 3.1 for an additional hour. Control ganglia lacking exposure to Bgt 3.1 were labeled heavily with fluorescence outlining the neuronal cell bodies (Fig. $3 A$ ). In contrast, ganglia treated with Bgt 3.1 contained neurons with the intense punctate labeling (Fig. $3 B$ ).

Internalization of bound R-2.2 could not be induced by Bgt 3.1 in the presence of high concentrations of Bgt 2.2 . Thus, CG neurons that were labeled with R-2.2 and subsequently incubated with $1 \mu \mathrm{M}$ Bgt 2.2 along with Bgt 3.1 retained fluorescent labeling at the cell surface and lacked the characteristic internal punctate labeling (Fig. 4). It is possible that the high concentrations of Bgt 2.2 prevented internalization by saturating the Bgt 2.2 high affinity binding site. Under the conditions used, R-2.2 itself did not saturate the Bgt 2.2 binding sites. This was demonstrated by competition studies in which Bgt 2.2 and R-2.2 were compared in their abilities to block ${ }^{125} \mathrm{I}-$ Bgt 2.2 binding (Table I). With the standard labeling conditions, $50 \mathrm{~nm}$ for $1 \mathrm{hr}, \mathrm{R}-2.2$ blocked about one-third of the sites, while Bgt 2.2 blocked nearly all of them. Higher concentrations of R-2.2 blocked a larger fraction of the sites.

Immunological confirmation of Bgt 2.2 internalization. Further evidence for the internalization of bound Bgt 2.2 was obtained by using ${ }^{125} \mathrm{I}$-Bgt 2.2 together with anti-Bgt 2.2 antibodies. The strategy was to determine what fraction of the ${ }^{125} \mathrm{I}$-Bgt 2.2 bound to intact cells remained accessible to antibodies before and after treatment with Bgt 3.1. Since antibodies cannot readily cross the membrane of intact cells, a decrease in the amount of antigen - antibody complex formed on intact cells would imply internalization of the labeled ligand by the cell. To determine the optimum level of antiserum for the assay, cultures of CG neurons were labeled with ${ }^{125} \mathrm{I}$-Bgt 2.2 , washed, incubated with various concentrations of antiserum, washed again, and homogenized. The cell homogenate then was incubated with fixed Staphylococcus aureus and centrifuged to collect bound antigen - antibody complex. With saturating levels of antiserum, about two-thirds of the neuronally bound Bgt 2.2 could be recovered as antigen-antibody complex specifically bound to the Staphylococcus (Fig. 5). Less than complete precipitation of the complex is expected in the Staphylococcus assay when few antibodies are bound per antigen (Kessler, 1975), as might occur when Bgt 2.2 is associated with membrane sites. Incubation of unbound ${ }^{125}$ I-Bgt 2.2 with excess antiserum followed by Staphylococcus treatment led to complete precipitation $(98 \%)$ of the radioactivity.

Bgt 3.1 treatment significantly reduced the amount of neuronally bound ${ }^{125} \mathrm{I}-\mathrm{Bgt} 2.2$ that could interact with antibody and be precipitated specifically as antigen - antibody complex. A small reduction was observed when neurons were labeled initially with a high concentration of ${ }^{125} \mathrm{I}$-Bgt 2.2 (9 $\mathrm{nM}$ ) (Table II). A large reduction was seen for neurons labeled with a low concentration of ${ }^{125} \mathrm{I}$ - 

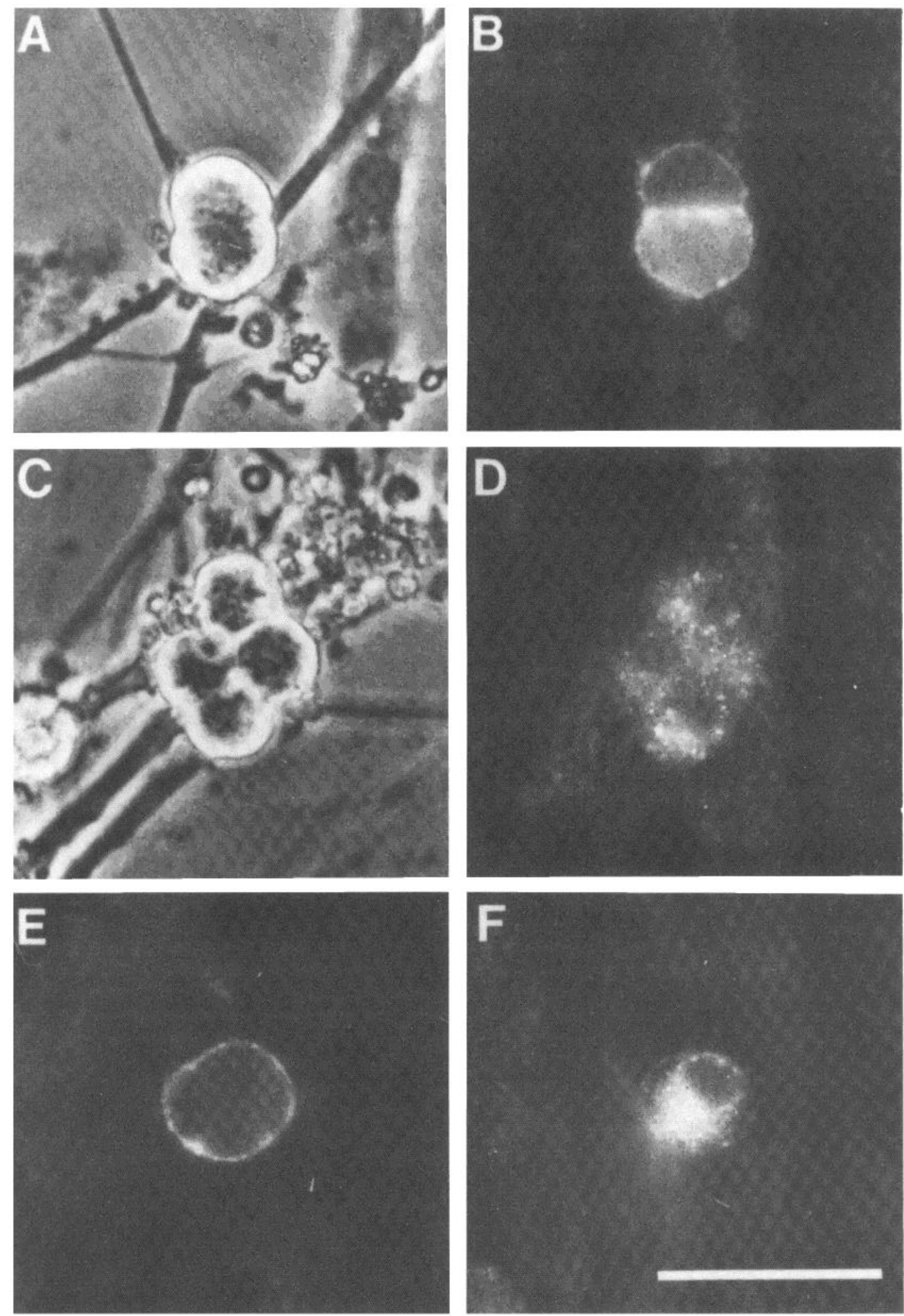

Figure 2. Internalization of R-2.2 bound to CG neurons in cell culture. One-week-old CG cultures grown on glass bottom dishes were incubated in R-2.2 as indicated below and then were examined by phase and fluorescence microscopy. $A$, Phase micrograph of two CG neurons incubated $2 \mathrm{hr}$ at $37^{\circ} \mathrm{C}$ in $50 \mathrm{~nm}$ R-2.2. B, Fluorescence micrograph of same cells as in $A$. $C$, Phase micrograph of a cluster of four neurons incubated $1 \mathrm{hr}$ at $37^{\circ} \mathrm{C}$ in $50 \mathrm{nM} \mathrm{R}-2.2$ followed by a $2 \mathrm{nd} \mathrm{hr}$ at $37^{\circ} \mathrm{C}$ in R-2.2 plus $0.2 \mu \mathrm{M}$ Bgt 3.1. $D$, Fluorescence micrograph of same cell cluster shown in $C$. $E$, Fluorescence micrograph of a neuron labeled with $50 \mathrm{~nm}$ R-2.2 for $75 \mathrm{~min}$ at $37^{\circ} \mathrm{C}$, rinsed, and then incubated an additional $2 \mathrm{hr}$ in $0.2 \mu \mathrm{M}$ Bgt 3.1 at $4^{\circ} \mathrm{C}$. $F$, Fluorescence micrograph of a neuron treated as in $E$ except that, after the $4^{\circ} \mathrm{C}$ incubation, it was rinsed three times and then warmed to $37^{\circ} \mathrm{C}$ for $1 \mathrm{hr}$. In all cases, the fluorescent labeling was specific in that it did not occur when the cells were incubated in $0.2 \mu \mathrm{M}$ Bgt 2.2 before and during the incubation with R-2.2. Calibration bar: $50 \mu \mathrm{m}$. 

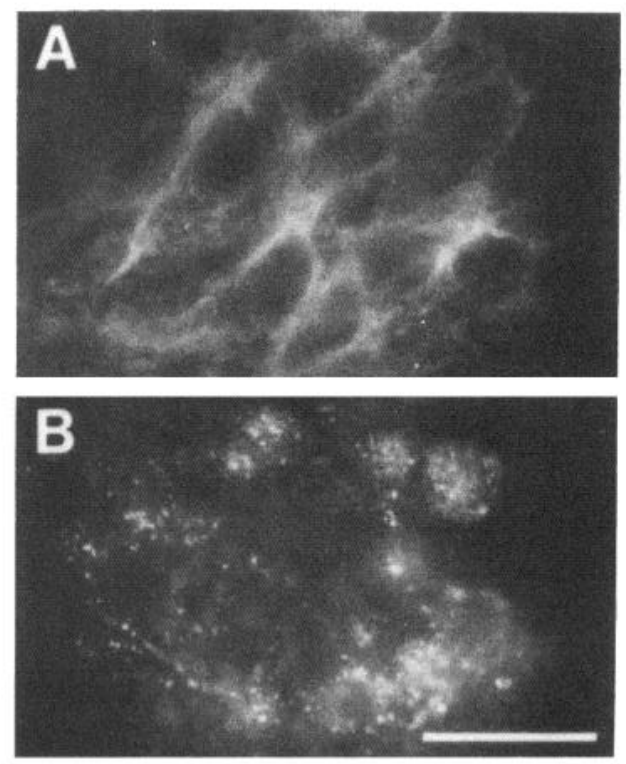

Figure 3. Internalization of R-2.2 bound to intact ciliary ganglia. Ganglia from 8-day-old chick embryos were incubated in culture medium $(0.2 \mathrm{ml})$ for $2 \mathrm{hr}$ at $37^{\circ} \mathrm{C}$ containing $(A) 50$ nM R-2.2 or $(B) \mathrm{R}-2.2$ for $1 \mathrm{hr}$ at $37^{\circ} \mathrm{C}$, followed by $1 \mathrm{hr}$ at $37^{\circ} \mathrm{C}$ in R-2.2 plus $0.2 \mu \mathrm{M}$ Bgt 3.1 and then were examined by fluorescence microscopy. Incubation of the ganglia in $1 \mu \mathrm{M}$ Bgt 2.2 for $1 \mathrm{hr}$ at $37^{\circ} \mathrm{C}$ prior to $\mathrm{R}-2.2$ treatment blocked the fluorescent labeling. Calibration bar: $50 \mu \mathrm{m}$.

Bgt $2.2(1 \mathrm{nM})$. As predicted from the R-2.2 studies, inclusion of an excess of Bgt $2.2(1 \mu \mathrm{M})$ in the incubation with Bgt 3.1 prevented the internalization of the bound ${ }^{125}$ I-Bgt 2.2. These results are consistent with the possibility that high concentrations of Bgt 2.2 may prevent the induced internalization by saturating the Bgt 2.2 binding sites. The fact that Bgt 3.1 achieved some internalization following labeling with $9 \mathrm{nM}{ }^{125} \mathrm{I}-\mathrm{Bgt} 2.2$, a concentration previously found to be saturating, may reflect the fact that some of the bound ${ }^{125} \mathrm{I}$-Bgt 2.2 dissociates during the incubation with Bgt 3.1 (see below).

When internalization was blocked by incubation at low temperature, Bgt 3.1 did not reduce the amount of bound Bgt 2.2 accessible to antibody (Table II). Low temperature did not prevent Bgt 3.1 binding (Fig. 2, $E$ and $F$; see Fig. 10). Accordingly, it is unlikely that Bgt 3.1 reduced the accessibility of bound Bgt 2.2 for antibody by interfering in a simple steric manner. Instead, the temperature dependence confirms the observations made with R-2.2 and supports the interpretation that the reduced accessibility reflects internalization of the bound Bgt 2.2.

Fate of internalized Bgt 2.2. The fate of internalized ${ }^{125} \mathrm{I}$-Bgt 2.2 was examined first by measuring the rate of release of radioactivity from the cells. Cultures of CG neurons were labeled with ${ }^{125} \mathrm{I}$-Bgt 2.2 under nonsaturating conditions ( $1 \mathrm{nM}, 1 \mathrm{hr})$, washed, incubated either with or without Bgt $3.1\left(0.2 \mu \mathrm{M}, 2 \mathrm{hr}\right.$ at $\left.37^{\circ} \mathrm{C}\right)$, and washed again. The release of radioactivity from the cultures then was followed over a 5 -hr period. The amount of ${ }^{125} \mathrm{I}-\mathrm{Bgt}$ 2.2 initially associated with the cells was similar for cultures incubated with and without Bgt 3.1. No significant difference was observed for the rate of release from the two kinds of cultures. Half-times of 2 to $3 \mathrm{hr}$ were
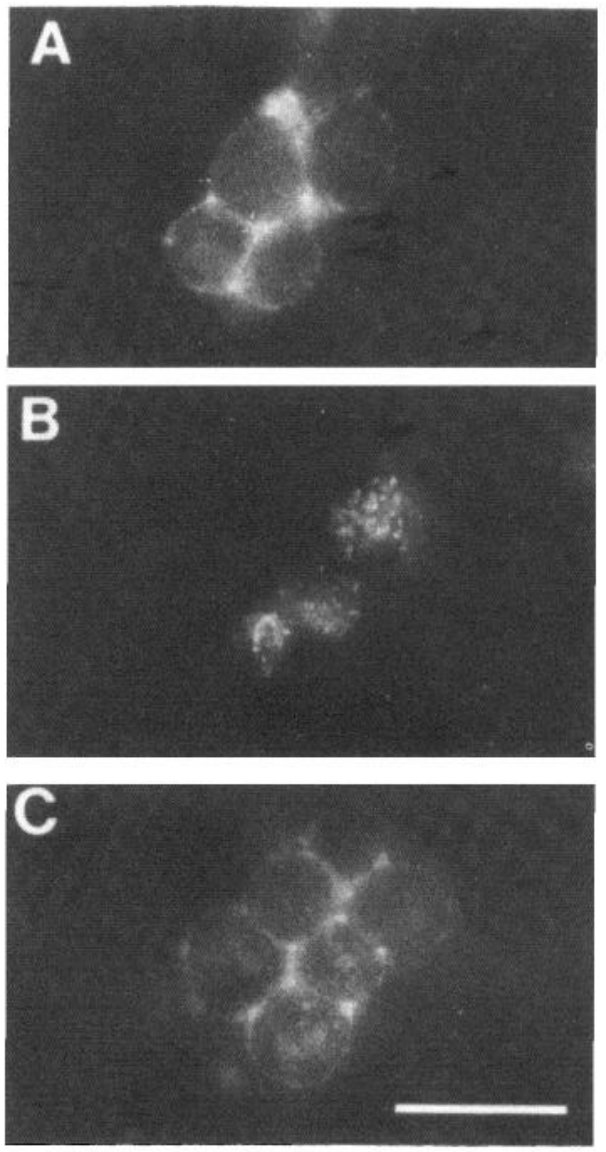

Figure 4. Blockade of R-2.2 internalization. CG neuron cultures labeled with R-2.2 were examined by fluorescence microscopy as described in Figure 2. A, A cluster of CG neurons after incubation for $2 \mathrm{hr}$ at $37^{\circ} \mathrm{C}$ in $50 \mathrm{~nm} \mathrm{R}-2.2$. B, A cluster of neurons treated as in $A$ except that $0.2 \mu \mathrm{M} \mathrm{Bgt} 3.1$ was included during the 2 nd $\mathrm{hr}$ at $37^{\circ} \mathrm{C}$. $C$, A cluster of neurons treated as in $B$ except that $1 \mu \mathrm{M}$ Bgt 2.2 was included with the Bgt 3.1 during the $2 \mathrm{nd} \mathrm{hr}$ at $37^{\circ} \mathrm{C}$. Calibration bar: $50 \mu \mathrm{m}$.

\section{TABLE I}

Blockade of Bgt 2.2 binding sites by $R-2.2$

CG cultures were incubated for $1 \mathrm{hr}$ at $37^{\circ} \mathrm{C}$ with $0.5 \mathrm{ml}$ of culture medium containing the indicated competing ligands. ${ }^{125} \mathrm{I}-\mathrm{Bgt} 2.2(9 \mathrm{nM})$ then was added and the incubation was continued for $1 \mathrm{hr}$ at $37^{\circ} \mathrm{C}$. The cultures then were washed and assayed for bound radioactivity. The values represent the mean $\pm \mathrm{SE}$ for the number of cultures indicated in parentheses. Binding observed in the absence of a competing ligand was defined as $100 \%$, while binding obtained in the presence of $1 \mu \mathrm{M}$ Bgt 2.2 was defined as $0 \%$.

\begin{tabular}{lc}
\hline Competing Ligand & ${ }^{125}$ I-Bgt 2.2 Binding \\
\hline & $\%$ \\
50 nM Bgt 2.2 & $3 \pm 3(6)$ \\
50 nM R-2.2 & $67 \pm 5(6)$ \\
$0.3 \mu$ M R-2.2 & $23 \pm 4(3)$ \\
$0.5 \mu$ R R-2.2 & $12 \pm 6(3)$ \\
\hline
\end{tabular}

obtained for the rate of release at $37^{\circ} \mathrm{C}$ (Fig. 6). Similar results were obtained when release was measured from cultures labeled under saturating conditions $\left(15 \mathrm{nM}{ }^{125} \mathrm{I}\right.$ Bgt $2.2,1 \mathrm{hr}$ ) at the outset.

The form of the released radioactivity was examined to determine if degradation of the internalized Bgt 2.2 


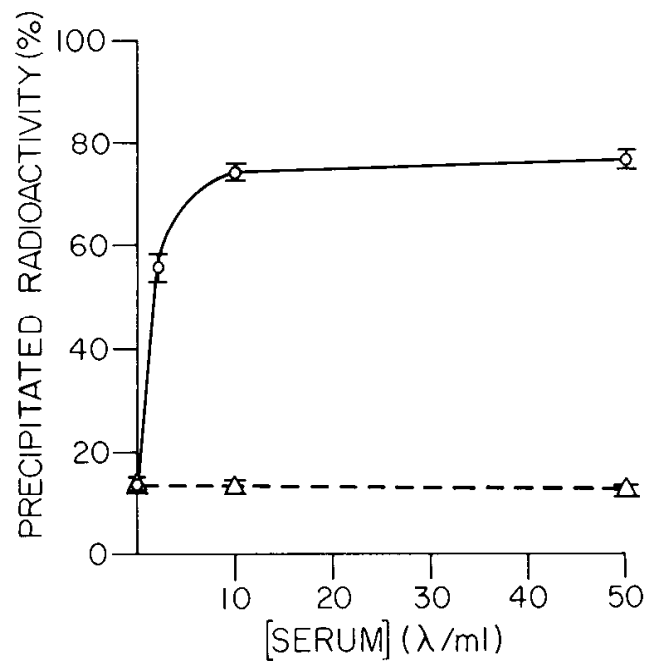

Figure 5. Access of anti-Bgt 2.2 antibodies to ${ }^{125} \mathrm{I}$-Bgt 2.2 bound to $\mathrm{CG}$ neurons. $\mathrm{CG}$ neurons grown for 5 days were labeled with $9 \mathrm{nM}{ }^{125} \mathrm{I}$-Bgt 2.2 for $1 \mathrm{hr}$ at $37^{\circ} \mathrm{C}$ to saturate the Bgt 2.2 binding sites. The cultures then were rinsed and incubated with the indicated concentrations of sera, homogenized, and mixed with Staphylococcus aureus to precipitate the radioactive antigen -antibody complexes. $\mathrm{O}-\mathrm{O}$, Anti-Bgt 2.2 antiserum; each point represents the mean of six cultures. $\triangle---\triangle$, Non-immune serum; each point represents the mean of four cultures. Bars indicate the SE.

TABLE II

Accessibility of cell-associated ${ }^{125}$ I-Bgt 2.2 to anti-Bgt 2.2 antiserum after Bgt 3.1 treatment

$\mathrm{CG}$ neuron cultures were labeled by incubation for $1 \mathrm{hr}$ at $37^{\circ} \mathrm{C}$ in the indicated concentration of ${ }^{125} \mathrm{I}$-Bgt 2.2 . The cultures then were rinsed and incubated in fresh medium containing the indicated additions $(0.2 \mu \mathrm{M}$ Bgt 3.1 and $1 \mu \mathrm{M}$ Bgt 2.2$)$ for either 40 or 120 min at $4^{\circ} \mathrm{C}$ or $37^{\circ} \mathrm{C}$ as shown. Incubations at $4^{\circ} \mathrm{C}$ were carried out in PBSS containing $1 \mathrm{mg} / \mathrm{ml}$ of ovalbumin. Then, the cultures were assayed with anti-Bgt 2.2 antiserum to determine the fraction of cell-associated radioactivity that remained accessible to antibodies. Background values were obtained by assaying cultures with non-immune serum instead of anti-Bgt 2.2 antiserum. Such values were about $10 \%$ of the experimental values and have been subtracted. The results are expressed as the fraction of the total cell-associated radioactivity that was spccifically precipitated by the anti-Bgt 2.2 antiserum when mixed with fixed Staphylococcus aureus. The values represent the mean $\pm \mathrm{SE}$ of the number of cultures shown in parentheses. The amount of labeling obtained with $1 \mathrm{nM}{ }^{125} \mathrm{I}-\mathrm{Bgt} 2.2$ was about $30 \%$ of that obtained with 9 $\mathrm{nM}$, as expected from Figure $1 B$.

\begin{tabular}{|c|c|c|c|}
\hline Label Period & Chase Period & \multirow{2}{*}{ Time } & $\begin{array}{c}{ }^{125} \text { I-Bgt } 2.2 \text { - Anti- } \\
\text { gen-Antibody Com- } \\
\text { plex }\end{array}$ \\
\hline${ }^{1: 25} \mathrm{I}-\mathrm{Bgt} 2.2$ & Addition & & $\begin{array}{c}\text { Percent } \\
\text { of Total } \\
{ }^{125} \mathrm{I}-\mathrm{Bgt} 2.2\end{array}$ \\
\hline$n M$ & & $\min$ & \\
\hline 9 & None & 40 & $67 \pm 2(8)$ \\
\hline 9 & Bgt 3.1 & 40 & $43 \pm 3(8)$ \\
\hline 9 & Bgt $3.1+2.2$ & 40 & $71 \pm 2(8)$ \\
\hline 1 & None & 40 & $67 \pm 2(8)$ \\
\hline 1 & Bgt 3.1 & 40 & $20 \pm 2(8)$ \\
\hline 1 & None & 120 & $55 \pm 1(6)$ \\
\hline 1 & Bgt 3.1 & 120 & $13 \pm 1(7)$ \\
\hline 1 & None, $4^{\circ} \mathrm{C}$ & 120 & $69 \pm 2(6)$ \\
\hline 1 & Bgt $3.1,4^{\circ} \mathrm{C}$ & 120 & $66 \pm 2(6)$ \\
\hline
\end{tabular}

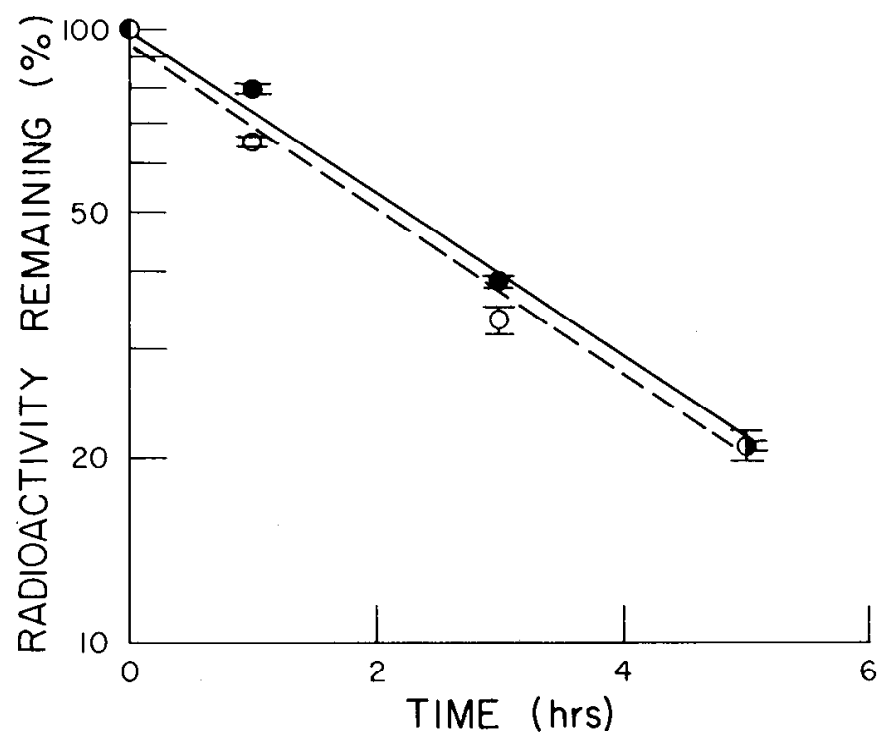

Figure 6. Release of radioactivity from CG neurons labeled with ${ }^{125} \mathrm{I}$-Bgt 2.2. CG neuron cultures were incubated with $1 \mathrm{nM}$ ${ }^{125} \mathrm{I}-\mathrm{Bgt} 2.2$ for $1 \mathrm{hr}$ at $37^{\circ} \mathrm{C}$ to label approximately one-third of the Bgt 2.2 binding sites. The cultures then were rinsed and incubated for $40 \mathrm{~min}$ at $37^{\circ} \mathrm{C}$ either in plain medium $(\mathrm{O}---\mathrm{O})$ or in medium with $0.2 \mu \mathrm{M} \mathrm{Bgt} 3.1(-)$ ) to induce internalization. After another rinse, the cultures were fed with fresh medium and returned to $37^{\circ} \mathrm{C}$ to begin the release period. At the indicated times, the cultures were examined to determine the amount of radioactivity retained by the cells. Each point represents the mean of three cultures. The bars indicate the SE.

had occurred. Cultures were labeled with $1 \mathrm{nM}{ }^{125} \mathrm{I}-\mathrm{Bgt}$ 2.2, treated with Bgt 3.1, washed, and incubated for 6.5 $\mathrm{hr}$. The culture medium then was recovered and fractionated on a P-2 column. Over half of the released radioactivity was recovered in the included volume of the column, indicating that extensive breakdown of the bound toxin had occurred (Fig. 7). In control cultures lacking Bgt 3.1 treatment (Fig. 7) or in cultures incubated in 1 $\mu \mathrm{M}$ Bgt 2.2 along with the Bgt 3.1 (not shown), less than a quarter of the released radioactivity was recovered in the included volume and this presumably reflects normal metabolic turnover of the membrane receptor (see "Discussion"). Thus, the rate of release of labeled material from the neurons with and without Bgt 3.1 treatment was similar, but more of the bound ${ }^{125} \mathrm{I}$-Bgt 2.2 was released in a degraded form when internalization occurred.

Sympathetic neurons. Bgt 3.1 was able to internalize bound Bgt 2.2 on chick sympathetic neurons in cell culture as it did on CG neurons. Cultures of sympathetic neurons were labeled with R-2.2 and then treated with Bgt 3.1 and examined by fluorescence microscopy. Control cultures lacking Bgt 3.1 treatment contained neurons with heavy surface labeling (Fig. $8 A$ ). Neurons treated with Bgt 3.1 had the characteristic internal punctate labeling observed for $\mathrm{CG}$ neurons after similar treatment (Fig. $8 B$ ). Internalization of bound R-2.2 was blocked when a saturating level of Dendroaspis viridis long toxin $(1 \mu \mathrm{M})$, an $\alpha$-toxin that binds to Bgt 2.2 binding sites 


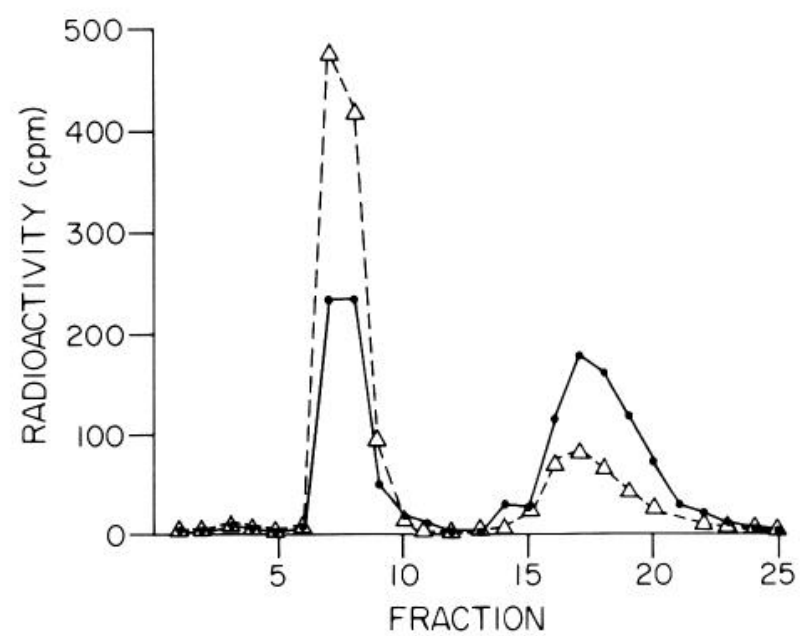

Figure 7. Degradation of ${ }^{125} \mathrm{I}-\mathrm{Bgt} 2.2$ bound to $\mathrm{CG}$ neurons. CG cultures prepared with five dissociated ganglia per $16-\mathrm{mm}$ well were labeled with $1 \mathrm{~nm}{ }^{125} \mathrm{I}-\mathrm{Bgt} 2.2$, rinsed, and incubated in medium with $0.2 \mu \mathrm{M}$ Bgt 3.1 as described in Figure 6. The cultures then were rinsed again and incubated $6.5 \mathrm{hr}$ at $37^{\circ} \mathrm{C}$ to permit release of the radioactivity. The recovered medium was analyzed by gel filtration through a P-2 column. $\triangle---\triangle$, Control culture; Bgt 3.1-treated culture. The leading peaks (fractions 7 to 9 ) are in the position expected for intact ${ }^{125} \mathrm{I}-\mathrm{Bgt} 2.2$ and larger components, while the trailing peaks (fractions 15 to 20 ) are in the position expected for $\operatorname{di}\left[{ }^{125} \mathrm{I}\right]$ iodo-L-tyrosine and other small molecular weight material.

(Patrick et al., 1980), was included in the incubation with Bgt 3.1 (Fig. $8 C$ ).

Internalization of bound Bgt 2.2 on sympathetic neurons was confirmed by antibody experiments. As with CG neurons, Bgt 3.1 treatment significantly reduced the fraction of bound ${ }^{125} \mathrm{I}-\mathrm{Bgt} 2.2$ that remained accessible to anti-Bgt 2.2 antiserum (Table III). Again, a high concentration of Bgt 2.2 blocked the effect of Bgt 3.1.

Specificity of Bgt 3.1. Two types of experiments were done to examine the specificity of the internalization induced by Bgt 3.1. The first was to determine whether all protein ligands that bound to specific receptors on the neurons were internalized after Bgt 3.1 treatment. The ligand tested was $\beta$-nerve growth factor ( $\beta$-NGF). Rhodamine-labeled $\beta$-nerve growth factor (R-NGF) was prepared and incubated with sympathetic neurons in cell culture. For many neurons, both the soma and processes were labeled with rhodamine fluorescence (Fig. 9A). No difference was observed after Bgt 3.1 treatment (Fig. $9 B$ ). The neurons retained the surface labeling and did not have the internal punctate labeling characteristic of internalized R-2.2. The R-NGF binding to sympathetic neurons was specific since incubation with $20 \mu \mathrm{M} \beta$-NGF for $30 \mathrm{~min}$ at $37^{\circ} \mathrm{C}$ prior to R-NGF treatment prevented the fluorescent labeling. Preincubation of the neurons in $0.2 \mu \mathrm{M}$ Bgt 3.1 for $30 \mathrm{~min}$ at $37^{\circ} \mathrm{C}$ did not reduce the amount of fluorescent labeling obtained subsequently with R-NGF, indicating that Bgt 3.1 did not compete for R-NGF binding sites and did not internalize them in the absence of R-NGF. These results suggest that at least one class of protein ligands bound to the neurons is not internalized by Bgt 3.1 treatment.
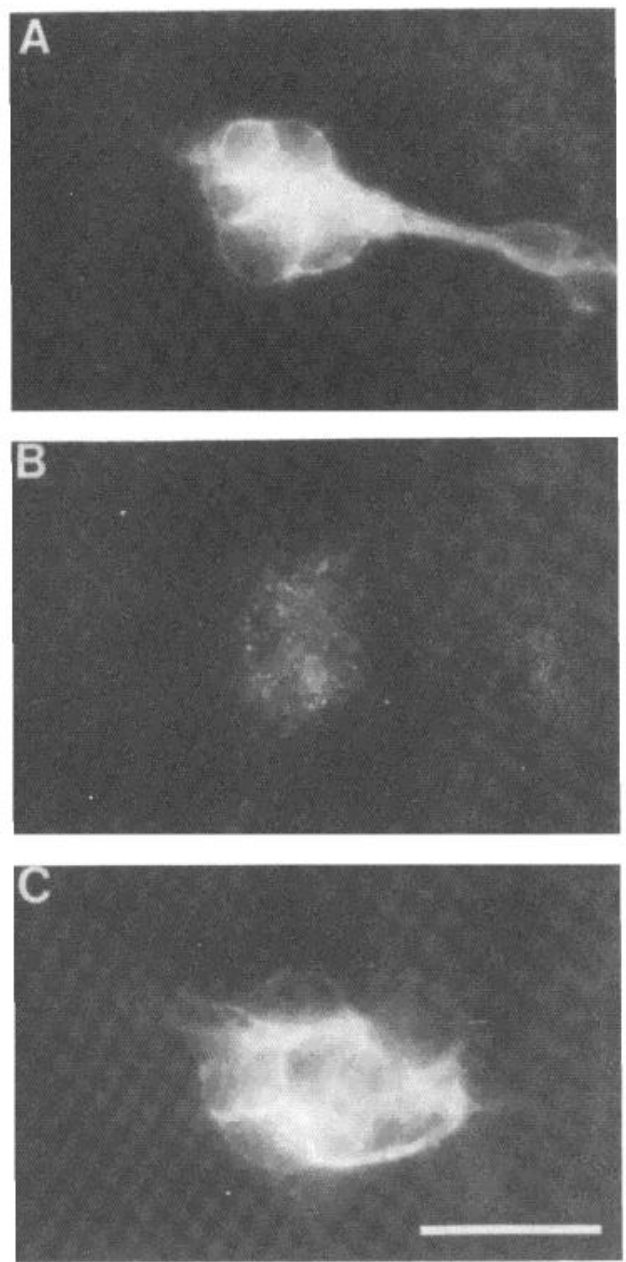

Figure 8. Internalization of R-2.2 on sympathetic neurons. Cultures of sympathetic neurons were incubated with $50 \mathrm{~nm} R$ 2.2 with and without Bgt 3.1 treatment and were examined by fluorescence microscopy. $A$, A cluster of neurons labeled with R-2.2 for $2 \mathrm{hr}$ at $37^{\circ} \mathrm{C}$. B, A cluster of neurons treated as in $A$ except that $0.2 \mu \mathrm{M}$ Bgt 3.1 was included in the $2 \mathrm{nd} \mathrm{hr}$ of the incubation. $C$, A cluster of neurons treated as in $B$ except that $1 \mu \mathrm{M}$ Dendroaspis viridis long toxin was included along with Bgt 3.1 in the $2 \mathrm{nd} \mathrm{hr}$ of incubation. Calibration bar: $50 \mu \mathrm{m}$.

TABLE III

Bgt 3.1-induced internalization of ${ }^{125} \mathrm{I}$-Bgt 2.2 on sympathetic neurons

Sympathetic neuron cultures were labeled with $1 \mathrm{nM}{ }^{125} \mathrm{I}$-Bgt 2.2 for $1 \mathrm{hr}$ at $37^{\circ} \mathrm{C}$ and were incubated for a $2 \mathrm{nd} \mathrm{hr}$ at $37^{\circ} \mathrm{C}$ in medium with the indicated additions $(0.2 \mu \mathrm{M}$ Bgt 3.1 and $1 \mu \mathrm{M}$ Bgt 2.2). The cultures then were assayed with anti-Bgt 2.2 antiserum to determine the fraction of cell-associated radioactivity that remained accessible to the antibodies as described in Table II. The values represent the mean $\pm \mathrm{SE}$ for the number of cultures shown in parentheses.

\begin{tabular}{|c|c|}
\hline Chase Period & $\begin{array}{c}{ }^{125} \mathrm{I} \text {-Bgt } 2.2 \text { - Antigen } \cdot \text { Antibody } \\
\text { Complex }\end{array}$ \\
\hline Addition & Percent of Total ${ }^{125} \mathrm{I}$-Bgt 2.2 \\
\hline None & $57 \pm 1(10)$ \\
\hline Bgt 3.1 & $25 \pm 1(10)$ \\
\hline Bgt $3.1+2.2$ & $66 \pm 2(10)$ \\
\hline
\end{tabular}



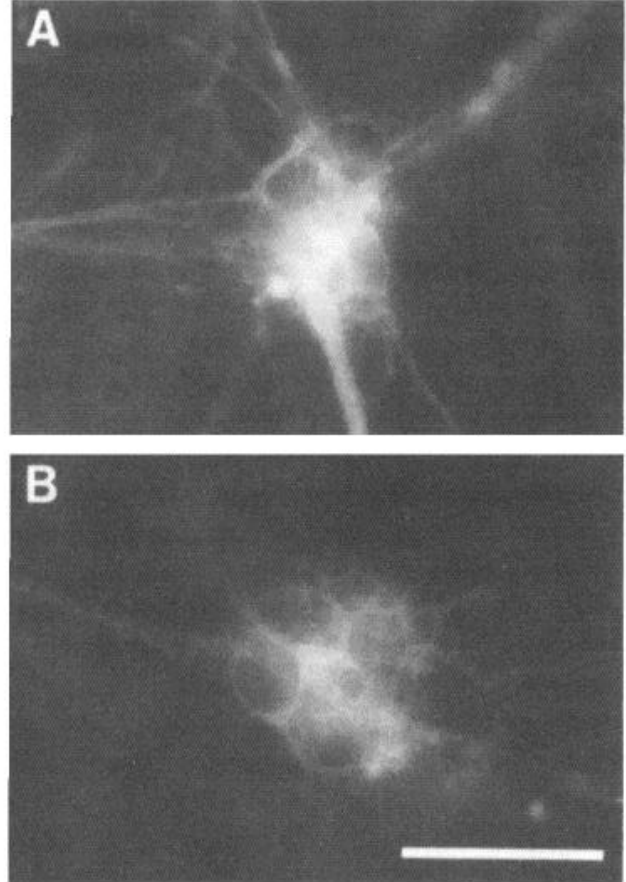

Figure 9. Binding of R-NGF to sympathetic neurons. Cultures of sympathetic neurons were incubated with R-NGF with and without Bgt 3.1 and were examined by fluorescence microscopy. $A$, A cluster of neurons labeled with $0.1 \mu \mathrm{M}$ R-NGF for $2 \mathrm{hr}$ at $37^{\circ} \mathrm{C}$. B, A cluster of neurons treated as in $A$ except that $0.2 \mu \mathrm{M}$ Bgt 3.1 was included for the $2 \mathrm{nd} \mathrm{hr}$ of the incubation. Calibration bar: $50 \mu \mathrm{m}$.

The second line of experiments examined whether Bgt 3.1 could internalize Bgt 2.2 bound to myotubes as well as neurons. Myotube cultures were labeled either with a saturating level of ${ }^{125} \mathrm{I}-\mathrm{Bgt} 2.2(9 \mathrm{nM})$ or with a subsaturating level ( $1 \mathrm{nM})$. The cultures then were washed, incubated with $0.2 \mu \mathrm{M}$ Bgt 3.1, and assayed for the fraction of bound ${ }^{125} \mathrm{I}$-Bgt 2.2 that remained accessible to antibodies as described for CG neurons. No evidence for induced internalization was obtained. Both for control cultures and for cultures treated with Bgt 3.1, 50 to $60 \%$ of the bound Bgt 2.2 could interact with antibody and be recovered in an antigen - antibody complex associated with the Staphylococcus (Table IV).

Mechanism of internalization. The observation that internalization could be blocked by high concentrations of Bgt 2.2 suggested that Bgt 3.1 might normally induce internalization of bound Bgt 2.2 by binding to unoccupied Bgt 2.2 sites. To determine whether Bgt 3.1 and Bgt 2.2 shared a common binding site, competition binding studies were carried out between ${ }^{125} \mathrm{I}$-Bgt 2.2 and Bgt 3.1 on $\mathrm{CG}$ neurons. Incubations were carried out at $4^{\circ} \mathrm{C}$ so that internalization would not occur. The cultures were incubated first in various concentrations of Bgt 3.1 for $1 \mathrm{hr}$ and then assayed for the number of unoccupied Bgt 2.2 sites remaining by adding ${ }^{125} \mathrm{I}$-Bgt 2.2 . Bgt 3.1 at $0.2 \mu \mathrm{M}$, the concentration used to induce internalization, blocked about two-thirds of the sites (Fig. 10).

If Bgt 3.1 triggers internalization by occupying Bgt 2.2 binding sites, then ligands which compete for the remaining Bgt 2.2 binding sites should prevent Bgt 3.1 from inducing internalization of bound Bgt 2.2. Previous stud-
TABLE IV

Failure of Bgt 3.1 to induce internalization of ${ }^{125}$ I-Bgt 2.2 on myotubes

Skeletal myotube cultures were labeled with the indicated concentration of ${ }^{125} \mathrm{I}-\mathrm{Bgt} 2.2$ for $1 \mathrm{hr}$ at $37^{\circ} \mathrm{C}$ and then were washed and incubated for a $2 \mathrm{nd} \mathrm{hr}$ at $37^{\circ} \mathrm{C}$ with or without $0.2 \mu \mathrm{M}$ Bgt 3.1 as indicated. The cultures then were assayed with anti-Bgt 2.2 antiserum to determine the fraction of cell-associated radioactivity that remained accessible to antibodies as described in Table II. Values represent the mean $\pm \mathrm{SE}$ of the number of cultures shown in parentheses.

\begin{tabular}{|c|c|c|}
\hline Label Period & Chase Period & $\begin{array}{l}{ }^{125} \text { I-Bgt } 2.2 \text { - Antigen. } \\
\text { Antibody Complex }\end{array}$ \\
\hline${ }^{125} \mathrm{I}$-Bgt 2.2 & Addition & $\begin{array}{c}\text { Percent } \\
\text { of Total } \\
125 \text { I-Bgt } 2.2\end{array}$ \\
\hline \multicolumn{3}{|l|}{$n M$} \\
\hline 9 & None & $61 \pm 1(6)$ \\
\hline 9 & Bgt 3.1 & $56 \pm 4(6)$ \\
\hline 1 & None & $55 \pm 3(6)$ \\
\hline 1 & Bgt 3.1 & $63 \pm 1(6)$ \\
\hline
\end{tabular}

ies have shown that cholinergic ligands can block Bgt 2.2 binding to autonomic neurons. Accordingly, several cholinergic ligands were tested for their effects on ${ }^{125} \mathrm{I}-\mathrm{Bgt}$ 2.2 binding and on Bgt 3.1-mediated internalization of Bgt 2.2 bound to the neurons. At the concentrations used, the drugs produced partial blockade of binding and partial blockade of internalization (Table V). Cholinergic ligands themselves did not induce internalization of ${ }^{125} \mathrm{I}$ Bgt 2.2 bound to the neurons (Table VI). Gel filtration studies with ${ }^{125} \mathrm{I}$-Bgt 2.2 and Bgt 3.1 on Sephadex G-50 columns indicated that Bgt 3.1 did not bind to ${ }^{125} \mathrm{I}-\mathrm{Bgt}$ 2.2 and did not cause aggregation of ${ }^{125} \mathrm{I}$-Bgt 2.2 free in solution (data not shown).

Blockade of ACh sensitivity. We previously reported that Bgt 3.1 blocks ACh sensitivity on CG neurons in culture (Ravdin and Berg, 1979). The present work demonstrates that Bgt 3.1 induces the internalization of Bgt 2.2 bound to the neurons. To examine the relationship between these two consequences of Bgt 3.1, we tested the effect of Bgt 3.1 on ACh sensitivity under conditions where internalization was prevented. CG neuron cultures were incubated first in $50 \mathrm{~nm} \mathrm{R}-2.2$ to label the cells and then in $1 \mu \mathrm{M}$ Bgt 2.2 to block internalization of the Bgt 2.2 binding sites. Bgt $3.1(0.2 \mu \mathrm{M})$ then was added and the cultures were examined by fluorescence microscopy to confirm that no internalization of the R-2.2 had occurred. Finally sensitivity to iontophoretically applied ACh was measured and compared to values obtained in control cultures lacking exposure to toxins and in cultures receiving only Bgt 3.1. In all cases, Bgt 3.1 was able to block almost all of the ACh sensitivity (Table VII). R-2.2 and Bgt 2.2 treatment alone had no significant effect on sensitivity. Clearly, Bgt 3.1 blockade of ACh receptor function can occur without internalization of Bgt 2.2 binding sites.

\section{Discussion}

Three lines of evidence indicate that Bgt 3.1 induces the internalization of Bgt 2.2 bound to chick autonomic neurons. First, neurons labeled with R-2.2 lost their surface labeling following Bgt 3.1 treatment and acquired 


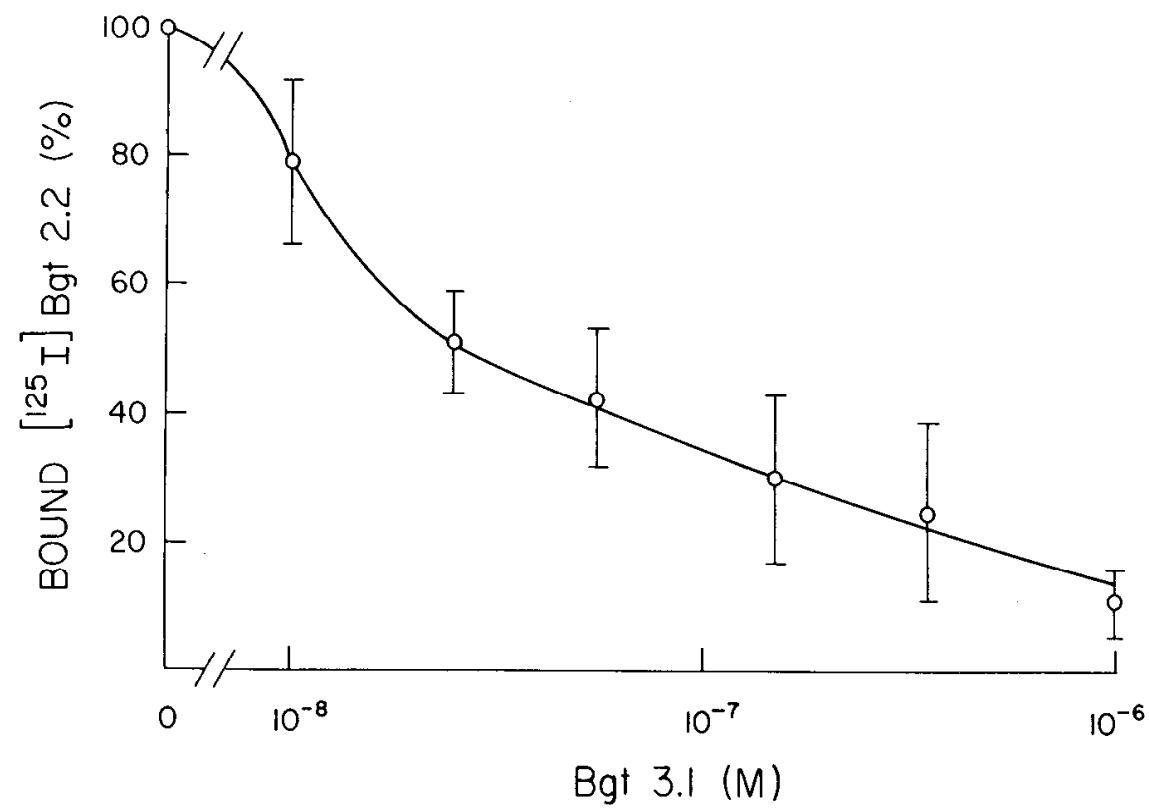

Figure 10. Blockade of ${ }^{125} \mathrm{I}$-Bgt 2.2 binding at $4^{\circ} \mathrm{C}$ by Bgt 3.1. The effect of Bgt 3.1 on Bgt 2.2 binding was carried out at $4^{\circ} \mathrm{C}$ so that the results would not be complicated by the internalization of binding sites. CG neuron cultures were incubated for $1 \mathrm{hr}$ with the indicated concentrations of Bgt 3.1 and for a $2 \mathrm{nd} \mathrm{hr}$ with Bgt 3.1 plus $10 \mathrm{~nm}$ ${ }^{125}$ I-Bgt 2.2. The cultures then were rinsed and assayed for bound radioactivity. Results have been expressed as a percentage of the specific binding obtained in control cultures lacking Bgt 3.1. Individual points represent the mean of either 9 or 12 cultures pooled from three or four experiments, respectively. The bars indicate the SE calculated from the variation in the means among experiments (i.e., $n=3$ or 4 , respectively). Radioimmune assays with ${ }^{125} \mathrm{I}-\mathrm{Bgt} 2.2$ and anti-Bgt 2.2 antiserum indicated that the two Bgt 3.1 preparations used here for the competition studies contained at most $0.6 \%$ and $0.02 \%$ Bgt 2.2 as a contaminant (D. K. Berg, unpublished observations). Such levels of Bgt 2.2 would not be adequate to account for the observed blockade.

\section{TABLE V}

Effects of cholinergic ligands on the binding and induced internalization of Bgt 2.2

To determine the effects of the ligands on Bgt 2.2 binding, CG neuron cultures were incubated with $10 \mathrm{nM}{ }^{125} \mathrm{I}-\mathrm{Bgt} 2.2$ for $1 \mathrm{hr}$ at $37^{\circ} \mathrm{C}$ in the presence of the indicated ligand, and the amount of the bound radioactivity was determined. To find the effects of the ligands on Bgt 3.1-induced internalization of Bgt 2.2, CG neuron cultures first were incubated in $2 \mathrm{nM}{ }^{125} \mathrm{I}$-Bgt 2.2 for $1 \mathrm{hr}$ at $37^{\circ} \mathrm{C}$ to label a fraction of the sites. The cultures then were rinsed, incubated in $0.1 \mu \mathrm{M}$ Bgt 3.1 with the competing ligand for $40 \mathrm{~min}$ at $37^{\circ} \mathrm{C}$, rinsed again, and assayed with anti-Bgt 2.2 antiserum to determine the fraction of cell-associated radioactivity that remained accessible to antibodies as described in Table II. The results are expressed as a percentage of the values obtained in the absence of a competing ligand. The numbers represent the mean $\pm \mathrm{SE}$ of three experiments (total of nine cultures per drug) for the binding data and two experiments (six cultures per drug) for the internalization data. Drug concentrations were $10 \mu \mathrm{M}$ for $d$-tubocurarine and $0.5 \mathrm{~mm}$ for carbamylcholine, decamethonium, and hexamethonium.

$\begin{array}{lcc}\text { Competing Ligand } & { }^{125} \mathrm{I} \text {-Bgt } 2.2 \text { Binding } & \begin{array}{c}{ }^{125} \mathrm{I} \text {-Bgt } 2.2 \text { Internaliza- } \\ \text { tion }\end{array} \\ & & \% \\ \text { d-Tubocurarine } & 30 \pm 9 & 16 \pm 5 \\ \text { Carbamylcholine } & 38 \pm 8 & 79 \pm 2 \\ \text { Decamethonium } & 31 \pm 6 & 71 \pm 1 \\ \text { Hexamethonium } & 59 \pm 11 & 79 \pm 1\end{array}$

TABLE VI

Failure of cholinergic ligands to induce ${ }^{125} \mathrm{I}$-Bgt 2.2 internalization CG neuron cultures were labeled with $0.5 \mathrm{nM}{ }^{125} \mathrm{I}-\mathrm{Bgt} 2.2$ for $1 \mathrm{hr}$ at $37^{\circ} \mathrm{C}$, washed four times, and then incubated for $1 \mathrm{hr}$ at $37^{\circ} \mathrm{C}$ in medium containing the indicated ligand (chase period) at $0.1 \mathrm{~mm}$. The cultures then were rinsed once and assayed with anti-Bgt 2.2 antiserum to determine the fraction of cell-associated radioactivity that remained accessible to antibodies as described in Table II. Values represent the mean \pm SE for five cultures each.

\begin{tabular}{lc}
\hline Chase Period & $\begin{array}{c}{ }^{125} \text { I-Bgt } 2.2-\begin{array}{c}\text { Antigen Antibody } \\
\text { Complex }\end{array} \\
\text { Addition }\end{array}$ \\
\hline None & $54 \pm 3$ \\
$d$-Tubocurarine & $45 \pm 3$ \\
Carbamylcholine & $56 \pm 1$ \\
Hexamethonium & $51 \pm 4$ \\
Atropine & $55 \pm 2$ \\
\hline
\end{tabular}

a punctate fluorescent labeling internally. Second, antibody studies demonstrated that ${ }^{125} \mathrm{I}$-Bgt 2.2 bound on neurons became inaccessible to anti-Bgt 2.2 after Bgt 3.1 treatment. Third, Bgt 3.1 treatment resulted in degradation of the bound ${ }^{125} \mathrm{I}-\mathrm{Bgt} 2.2$, presumably through an intracellular mechanism. 
TABLE VII

ACh sensitivity after toxin treatment

CG neurons grown with skeletal myotubes were incubated with the indicated toxins at $37^{\circ} \mathrm{C}$ for a total of $3 \mathrm{hr}$. For cultures receiving more than one toxin, the first toxin was present for the entire $3 \mathrm{hr}$, the second toxin for the last $2 \mathrm{hr}$, and the third toxin (where applicable) for the $3 \mathrm{rd} \mathrm{hr}$ only. Toxin concentrations were $0.2 \mu \mathrm{M}$ for Bgt 3.1, $1 \mu \mathrm{M}$ for Bgt 2.2 , and $50 \mathrm{nM}$ for R-2.2. ACh sensitivity was measured iontophoretically and is shown as the percentage of that obtained for the cultures before exposure to toxin. The values represent the mean $\pm \mathrm{SE}$ for the number of neurons shown in parentheses. It should be noted that the interpretation of SE values in this case is complicated by the fact that the distribution of sensitivities among neurons was unimodal but not normal (Ravdin and Berg, 1979).

\begin{tabular}{lc}
\hline \multicolumn{1}{c}{ Toxin } & Remaining ACh Sensitivity \\
\hline & $\%$ \\
Bgt 3.1 & $0 \pm 1(15)$ \\
Bgt 2.2, Bgt 3.1 & $1 \pm 1(13)$ \\
R-2.2, Bgt 2.2, Bgt 3.1 & $1 \pm 1(11)$ \\
R-2.2, Bgt 2.2 & $132 \pm 35(9)$ \\
\hline
\end{tabular}

The fraction of bound Bgt 2.2 that could be internalized by Bgt 3.1 treatment depended on the degree of saturation of the binding sites with Bgt 2.2. Under conditions where approximately $30 \%$ of the sites were occupied by Bgt 2.2, antibody studies suggested that Bgt 3.1 treatment may have internalized as much as $70 \%$ of the Bgt. 2.2 , i.e., the amount of cell-associated Bgt 2.2 that could be recovered as antigen -antibody complex was reduced by $70 \%$. When a larger fraction of the sites was occupied with Bgt 2.2, a smaller percentage was internalized. Maintaining a saturating concentration of Bgt 2.2 throughout the period of exposure to Bgt 3.1 completely blocked internalization. Studies on the internalization of epidermal growth factor by human epitheloid carcinoma cells have suggested that, in some cases, internalization may be rate limiting at high receptor occupancy (Haigler et al., 1978). The fact that saturating levels of Bgt 2.2 completely blocked internalization, however, suggests that the reduced efficiency of internalization with increased site occupancy may reflect a competition between Bgt 3.1 and Bgt 2.2, i.e., Bgt 3.1 may have to bind to some of the Bgt 2.2 sites in order to induce internalization.

The temperature shift experiments with R-2.2 and Bgt 3.1 indicated that Bgt 3.1-driven internalization was temperature dependent. The antibody experiments confirmed that Bgt 3.1 was unable to induce internalization of Bgt 2.2 at $4^{\circ} \mathrm{C}$. Competition binding studies at $4^{\circ} \mathrm{C}$ indicated that $\mathrm{Bgt} 3.1$ was able to block a large fraction of the Bgt 2.2 binding sites. The inhibition studies with $d$-tubocurarine and hexamethonium suggested a good correlation between the ability of a drug to occupy the Bgt 2.2 binding site and the ability to block the Bgt 3.1induced internalization of ${ }^{125} \mathrm{I}$-Bgt 2.2 . The correlations for carbamylcholine and for decamethonium, however, were less convincing. While these results are generally consistent with a mechanism for internalization in which Bgt 3.1 interacts directly with the Bgt 2.2 binding site, additional experiments will be necessary to confirm this. It remains possible that saturation of Bgt 2.2 binding sites with Bgt 2.2 or other ligands prevents internalization of the sites by altering their properties in the membrane and that this action is independent of their ability to prevent access of Bgt 3.1 to the sites.

It is likely that the internalization of Bgt 2.2 on neurons induced by Bgt 3.1 includes internalization of the Bgt 2.2 binding site as well. Spontaneous internalization of Bgt 2.2 on skeletal myotubes in culture has been shown to reflect ongoing metabolic turnover of the receptors in the membrane (Fambrough, 1979). Bgt 2.2 binding sites on chick sympathetic neurons also have been shown to undergo spontaneous metabolic turnover (Carbonetto and Fambrough, 1979). The neuronal sites have a halflife of about $11 \mathrm{hr}$ in the membrane whether or not they are occupied with Bgt 2.2. The induced internalization of Bgt 2.2 observed in the present studies is much more rapid: the maximum extent of internalization caused by $0.2 \mu \mathrm{M}$ Bgt 3.1 occurs within $40 \mathrm{~min}$ at $37^{\circ} \mathrm{C}$. Spontaneous turnover of the toxin - receptor complex, however, would account for the limited degradation of bound ${ }^{125}$ I-Bgt 2.2 observed in control cultures where induced internalization did not occur.

The effect of Bgt 3.1 on internalization of membrane components is not universal. It did not induce internalization of Bgt 2.2 bound to skeletal myotubes where the Bgt 2.2 binding site is known to be the muscle acetylcholine receptor nor did Bgt 3.1 induce the internalization of R-NGF bound to the surface of chick sympathetic neurons, though it did induce the internalization of Bgt 2.2 on sympathetic neurons. Using a heavily derivatized $R$ NGF and fluorescence microscopy with an image intensifier, Levi et al. (1980) detected spontaneous internalization of R-NGF by chick sensory neurons and PC12 cells. We observed no spontaneous internalization of $R$ NGF by chick sympathetic neurons, but the R-NGF used here was only lightly derivatized and 10-fold higher concentrations were necessary to observe labeling. Possibly, spontaneous internalization of R-NGF went undetected in the present experiments because it represented only a small fraction of the total sites labeled. The observed RNGF binding to sympathetic neurons was specific in the sense that it was saturable and did not occur at detectable levels on myotubes or fibroblasts in the cultures. The fact that Bgt 3.1 was unable to induce demonstrable internalization of the bound R-NGF supports the interpretation that the effect of Bgt 3.1 is specific: not all protein ligands on neuronal surfaces are internalized following Bgt 3.1 treatment. It might be argued that the $\mathrm{NGF}$ sites were saturated and, in analogy with the Bgt 2.2 sites, could not be internalized by $\mathrm{Bgt} 3.1$ under these conditions. Unlike the $\mathrm{Bgt} 2.2$ sites, however, pretreatment of the neurons with Bgt 3.1 produced no apparent decrement in the labeling obtained subsequently with $\mathrm{R}$ NGF, suggesting that Bgt 3.1 could neither occupy the NGF sites nor internalize them when unoccupied with NGF.

Numerous cases have been reported in which cells internalize proteins bound to their surfaces. Examples include certain peptide hormones, low density lipoprotein, and diphtheria toxin. One common mechanism of internalization is thought to be "receptor-mediated endocytosis" (Goldstein et al., 1979). In this case, a ligand 
binds to a receptor that either is located in a coated pit or is able to move to a coated pit. The coated pit then is thought to invaginate and form a coated vesicle (Goldstein et al., 1979) or a "receptosome" (Willingham and Pastan, 1980) containing the bound ligand inside of the cell. Internalization can also be mediated by "ligandinduced clustering" where multivalent ligands, such as concanavalin A, or divalent antibodies first "patch" components in the plane of the membrane. Invagination of the membrane and internalization of the components is thought to occur then, at least in some cases, without the aid of coated pits (Singer et al., 1978). Anti-Bgt 2.2 antiserum can induce the internalization of R-2.2 on CG neurons in culture (D. K. Berg, unpublished observations). We have not excluded the possibility that Bgt 3.1 is multivalent and acts in a similar manner, binding to and patching Bgt 2.2 sites.

The relationship between the Bgt 2.2 binding site and the neuronal $\mathrm{ACh}$ receptor remains unclear. It is interesting that Bgt 3.1 which blocks neuronal ACh sensitivity also induces the internalization of Bgt 2.2 on neurons. Bgt 3.3 also blocks neuronal ACh sensitivity (Ravdin and Berg, 1979) and induces internalization of Bgt 2.2 (P. M. Ravdin and D. K. Berg, unpublished observations). The effect of Bgt 3.1 on neuronal ACh sensitivity, however, does not depend on internalization of Bgt 2.2: Bgt 3.1 blocked ACh sensitivity even in the presence of Bgt 2.2 concentrations that prevented the internalization of bound R-2.2 on the neurons.

The studies reported here could be interpreted as implying that there are at least two classes of Bgt 3.1 binding sites on neurons, e.g., one class of sites that inhibits neuronal $\mathrm{ACh}$ sensitivity and a second class of sites (possibly the Bgt 2.2 binding site itself) that induces the internalization of Bgt 2.2 bound to the cells. Studies with radiolabeled $\mathrm{Bgt} 3.1$ will be necessary to determine the number and classes of Bgt 3.1 binding sites on neurons and to assess the value of Bgt 3.1 as a ligand for studying the regulation of neuronal $\mathrm{ACh}$ receptors. $\mathrm{Bgt}$ 3.1 is not an $\alpha$-neurotoxin in the conventional sense. Bgt 3.1 that has been absorbed with anti-Bgt 2.2 antibodies to remove trace amounts of Bgt 2.2 does not inhibit $\mathrm{ACh}$ sensitivity on chick skeletal myotubes in cell culture when incubated at $0.2 \mu \mathrm{M}$ for 1 to $2 \mathrm{hr}$ at $37^{\circ} \mathrm{C} \mathrm{(J.} \mathrm{F.}$ Margiotta and D. K. Berg, unpublished observations).

It is interesting that Bgt 3.1 can induce the internalization of Bgt 2.2 on neurons, while Bgt 2.2 cannot induce internalization of itself. Preliminary results with radiolabeled Bgt 3.1 suggest that Bgt 3.1 also can internalize itself (Nitkin, 1981). In addition to its value as a possible ligand for the neuronal $\mathrm{ACh}$ receptor, $\mathrm{Bgt} 3.1$ provides an unusual opportunity to examine the cellular mechanisms underlying the internalization of membrane components. A study of these processes may yield insights into the mechanisms by which neurons can regulate the number and distribution of their surface components.

\section{References}

Barald, K. F., and D. K. Berg (1978) High affinity choline uptake by spinal cord neurons in dissociated cell culture. Dev. Biol. 65: 90-99.

Brown, D. A., and L. Fumagalli (1977) Dissociation of $\alpha$-bun- garotoxin binding and receptor block in the rat superior cervical ganglion. Brain Res. 129: 165-168.

Burton, L. E., W. H. Wilson, and E. M. Shooter (1978) Nerve growth factor in mouse saliva. Rapid isolation procedures for and characterization of $7 \mathrm{~S}$ nerve growth factor. J. Biol. Chem. 253: 7807-7812.

Carbonetto, S., and D. M. Fambrough (1979) Synthesis, insertion into the plasma membrane, and turnover of $\alpha$-bungarotoxin receptors in chick sympathetic neurons. J. Cell Biol. 81 : 555-569.

Carbonetto, S. T., D. M. Fambrough, and K. J. Muller (1978) Nonequivalence of $\alpha$-bungarotoxin receptors and acetylcholine receptors in chick sympathetic neurons. Proc. Natl. Acad. Sci. U. S. A. 75: 1016-1020.

Chiappinelli, V. A., and E. Giacobini (1978) Time course of appearance of $\alpha$-bungarotoxin binding sites during development of chick ciliary ganglion and iris. Neurochem. Res. 3: 465-478.

Chiappinelli, V. A., and R. E. Zigmond (1978) $\alpha$-Bungarotoxin blocks nicotinic transmission in the avian ciliary ganglion. Proc. Natl. Acad. Sci. U. S. A. 75: 2999-3003.

Chiappinelli, V. A., J. B. Cohen, and R. E. Zigmond (1981) The effects of $\alpha$ - and $\beta$-neurotoxins from the venom of various srlakes on transmission in autonomic ganglia. Brain Res. 211: 107-126.

Fambrough, D. M. (1979) Control of acetylcholine receptors in skeletal muscle. Physiol. Rev. 59: 165-227.

Fumagalli, L., G. DeRenzis, and N. Miani (1978) $\alpha$-Bungarotoxin-acetylcholine receptors in the chick ciliary ganglion: Effects of deafferentation and axotomy. Brain Res. 153: 8798.

Goldstein, J. L., R. G. W. Anderson, and M. S. Brown (1979) Coated pits, coated vesicles, and receptor-mediated endocytosis. Nature 279: 679-685.

Haigler, H., J. F. Ash, S. J. Singer, and S. Cohen (1978) Visualization by fluorescence of the binding and internalization of epidermal growth factor in human carcinoma cells A431. Proc. Natl. Acad. Sci. U. S. A. 75: 3317-3321.

Hanley, M. P., V. A. Eterovic, S. P. Hawley, A. J. Herbert, and E. L. Bennett (1977) Neurotoxins of Bungarus multicinctus venom. Purification and partial characterization. Biochemistry 16: $5840-5848$.

Kessler, S. W. (1975) Rapid isolation of antigens from cells with a Staphylococcal protein A-antibody adsorbent: Parameters of the interaction of antibody-antigen complexes with protein A. J. Immunol. 115: 1617-1624.

Kouvelas, E. D., M. A. Dichter, and L. A. Greene (1978) Chick sympathetic neurons develop receptors for $\alpha$-bungarotoxin in vitro, but the toxin does not block nicotinic receptors. Brain Res. 154: 83-93.

Levi, A., Y. Shechter, E. J. Neufeld, and J. Schlessinger (1980) Mobility, clustering, and transport of nerve growth factor in embryonal sensory cells and in a sympathetic neuronal cell line. Proc. Natl. Acad. Sci. U. S. A. 77: 3469-3473.

Lowry, O. H., N. J. Rosebrough, A. L. Farr, and R. J. Randall (1951) Protein measurement with the Folin phenol reagent. J. Biol. Chem. 193: 265-275.

Nishi, R., and D. K. Berg (1977) Dissociated ciliary ganglion neurons in vitro: Survival and synapse formation. Proc. Natl. Acad. Sci. U. S. A. 74: 5171-5175.

Nishi, R., and D. K. Berg (1979) Survival and development of ciliary ganglion neurones grown alone in cell culture. Nature 277: 232-234.

Nishi, R., and D. K. Berg (1981) Two components from eye tissue that differentially stimulate the growth and development of ciliary ganglion neurons in cell culture. J. Neurosci. 1: 505-513.

Nitkin, R. M. (1981) The interaction of $\alpha$-toxins with autonomic 
neurons: Internalization and acetylcholine receptor function. Doctoral dissertation, University of California, San Diego.

Patrick, J., and W. R. Stallcup (1977a) $\alpha$-Bungarotoxin binding and cholinergic receptor function on a rat sympathetic nerve line. J. Biol. Chem. 252: 8629-8633.

Patrick, J., and W. B. Stallcup (1977b) Immunological distinction between acetylcholine receptor and the $\alpha$-bungarotoxinbinding component on sympathetic neurons. Proc. Natl. Acad. Sci. U. S. A. 74: 4689-4692.

Patrick, J., W. B. Stallcup, M. Zavanelli, and P. Ravdin (1980) Binding properties of a neurotoxin from the venom of the green mamba, Dendroaspis viridis. J. Biol. Chem. 255: 526533.

Ravdin, P., and D. Axelrod (1977) Fluorescent tetramethyl rhodamine derivatives of $\alpha$-bungarotoxin: Preparation, separation, and characterization. Anal. Biochem. 80: 585-592.
Ravdin; P. M., and D. K. Berg (1979) Inhibition of neuronal acetylcholine sensitivity by $\alpha$-toxins from Bungarus multicinctus venom. Proc. Natl. Acad. Sci. U. S. A. 76: 2072-2076.

Singer, S. J., J. F. Ash, L. Y. W. Bourguignon, M. H. Heggeness, and D. Louvard (1978) Transmembrane interactions and the mechanisms of transport of proteins across membranes. J. Supramol. Struct. 9: 373-389.

Varon, S., J. Nomura, and E. M. Shooter (1968) Reversible dissociation of the mouse nerve growth factor protein into different subunits. Biochemistry 7: 1296-1303.

Vogel, Z., A. J. Sytkowski, and M. W. Nirenberg (1972) Acetylcholine receptors of muscle grown in vitro. Proc. Natl. Acad. Sci. U. S. A. 69: 3180-3184.

Willingham, M. C., and I. Pastan (1980) The receptosome: An intermediate organelle of receptor-mediated endocytosis in cultured fibroblasts. Cell 21: 67-77. 